\title{
The Effect of Extraction Method, Bleaching and Clarification Processes on Quality Second Grade Siwi Date Dibs
}

\author{
Hanafy A. Hashem ${ }^{1}$, Hasan H. Abd El-Daym ${ }^{1}$, Gamal A. A. El-Sharnouby ${ }^{1}$, Salwa M. A. Farghal ${ }^{2}$, \\ Hossameldin A. Badr ${ }^{2}$ \\ ${ }^{1}$ Food Science and Technol. Dept., Faculty of Agric., Al-AzharUniv., Cairo, Egypt \\ ${ }^{2}$ Food Science, Agric-industrialization Unit, Plant Production Department, Desert Research Center, Cairo, Egypt
}

Email address:

hanafyhashem@hotmail.com (H. Abdel-aziz Hashem),ssbm2015@yahoo.com (H. H. A. El-Daym), gamali59@yahoo.com (G. A. A. El-Sharnouby), salwafarghal@hotmail.com (S. M. A. Farghal), hosmoon2014@gmail.com (H. A. Badr).

\section{To cite this article:}

Hanafy A. Hashem, Hasan H. Abd El-Daym, Gamal A. A. El-Sharnouby, Salwa M. A. Farghal, Hossameldin A. Badr. The Effect of Extraction Method, Bleaching and Clarification Processes on Quality Second Grade Siwi Date Dibs. American Journal of Applied Scientific Research. Vol. 3, No. 6, 2017, pp. 87-93. doi: 10.11648/j.ajasr.20170306.13

Received: March 7, 2017; Accepted: March 29, 2017; Published: November 30, 2017

\begin{abstract}
Second grade Siwi date palm fruits in Baharia Oasis were used forproduction of high quality date syrup (Dibs). Physical and chemical characteristics of Siwi date fruits (second grade) as well as quality parameters of Siwi date extract as affected by bleaching and clarification treatments were investigated. Also, quality parameters of the obtained dibs by different methods and treatments were examined. Physical and chemical characteristics of Siwi date illustrated that, fruit weight, flesh/pit ratio, fruit length, fruit diameter, T.S.S, total and reducing sugars, crude protein, ash, soluble pectin and tannins were $10.0 \mathrm{~g}, 6.40,3.46 \mathrm{~cm}, 2.22 \mathrm{~cm}, 81.40 \%, 91.41 \%, 86.78 \%, 2.76 \%, 0.83 \%, 1.55 \%$ and $0.27 \%$, respectively. Granular activated charcoal (G.A.C) is more effective bleaching treatment than powder activated charcoal (P.A.C), Also, liming phosphatation is more effective clarification treatment than centrifugation with filtration. Quality dibs results indicated that, the highest values of T.S.S, total and reducing sugars and date syrup yield were recorded for the dibs samples extracted at $75^{\circ} \mathrm{C}$ and $96^{\circ} \mathrm{C}$ and concentrated under vacuum while the lowest values were recorded for commercial sample(except yield), also, clarification processed sample recorded the lowest browning index, ash and pectin contents, while the highest values of these parameter were recorded for commercial sample. Sensory quality parameters demonstrated that, the highest taste and flavor scores were recorded for the extracted sample at $96^{\circ} \mathrm{C}$ with bleaching by GAC then concentrated under vacuum while the extracted sample by blender at room temperature (with or without clarification treatment) had the highest color scores. In relation to microbial quality, results showed that, microwave extraction followed by concentration at $100 \%$ power level recorded the highest microbial quality (the lowest counts of bacteria, yeast and mould, and coliform group) followed by sample extracted at $96^{\circ} \mathrm{C}$ and then concentrated under vacuum.
\end{abstract}

Keywords: Date Palm \& Syrup (Dibs), Quality Parameters, Methods and Treatments, Date Extraction, Bleaching and Clarification, Physical and Chemical Characteristics, Sensory Evaluation of Dibs

\section{Introduction}

Date palm (Phoenix dactylifera L.) is one of the oldest cultivated tree crops and one of the most important fruit trees in many countries in the world, especially in Islamic and Arabian countries.(Ashraf andHamidi-Esfahani,2011).Egypt lies in the first largest date producer among world countries. Egypt production reached about 1.4 million Tons. Date cultivars are classified on the basis of texture of the ripe fruit into three generally accepted categories soft, semi-dry and dry types (Barreveld, 1993). In Egypt, soft dates represent about $79.5 \%$ of the total production. Meghal, Hayani, Zaghloul and Samani varieties represent about 24.7, 25.2, 7.4 and $4.4 \%$, respectively of the total production. Semi-dry dates represent about $19.2 \%$ and Siwi date variety is the most important semi-dry date in Egypt, represents about $13.2 \%$ of the total production. While, dry date varieties represent, only about $1.3 \%$ of the total production (MALR, 2001). Most of the produced dates are consumed directly at their Khalal, 
Rutab and Tamr stages, with little or no further processing. Recently, date producing countries gave more attention to the improvement and development of date processing. Many products such as date syrup, vinegar, alcohol and liquid sugar are successfully marketed (Yousif et al., 1987). Several studies had been carried out to incorporate dates in different food products such as bakery items, date bars, beverages, jam, jelly and sheets (El-Samahy et al., 2003; El-Samahy and Youssef, 2009; Mostafa et al., 2002). One of the important products of processed dates is syrup, which is mostly produced from low quality and non-marketable dates. (Almaan and Mohamed,1991). Date syrup also has been used as a sweetener in food industry, because most of its carbohydrates are in the form of glucose and fructose, they easily passes into the blood without digestion. This is nutritionally important, especially for babies, children, sportsmen and in situations demanding urgent energy, (Batu,1993). Processing date fruits into date syrup is a way to preserve the fruits and to reduce transportation and storage costs and could open new outlets for date fruits. Giza Governorate produced about 76772 tons, most of them were produced from Baharia oasis region, where its production reached 35 thousand tons (Agri.Res.Cen.,2016). The rejected ratio of Siwi date reached about 15\% (3937 tons) of the total date production of Baharia oasis, mainly used in animal feeding. So, it is very important to utilize these quantities in date dibs production. This study aims to use second grade Siwi dates to obtain date dibs by different methods and treatments to enhance the quality of date dibs.

\section{Materials and Methods}

Materials:

Second grade of Siwi dates variety (semi-dry) (Phoenix dactylifera L.) at tamr stage was used to prepare the date dibs in this investigation. It was obtained from date packing victory, Mendisha village, Baharia Oasis region, Giza, Egypt.

Powder activated charcoal and Granular activated charcoal were obtained from paints and chemical industries co., Egypt.

Calcium oxide was obtained from El-Gomhouria pharmaceutical co., Egypt.

Phosphoric acid was obtained from El-Nasr pharmaceutical chemicals co., Egypt.

Commercial date dibs was obtained from Local Market.

Methods:

Date fruits were cleaned, pitted and the flesh was cut into small pieces and kept refrigerated in sealed polyethylene bags for processing and analyses.

Date extraction:

Three methods have been used to extract the soluble solids from Siwi date fruits pulp,(Blending, water bath and Microwave methods)as follow:

\subsection{Novel Extraction Method by Microwave}

$100 \mathrm{~g}$ cleaned pitted Siwi date fruits were blended with water at water/date ratio of $3: 1$ in a glass beakers at 50,80 and $100 \%$ power level (PL) of microwave oven. T.S.S of the mixture was determined at two minutes intervals. The process was continued till T.S.S of the extract reached its maximal level. Bleaching process was carried out for sample $100 \%$ power level only.

\subsection{Conventional Extraction Methods and Divided into Two Methods}

(a)Blender method

$100 \mathrm{~g}$ of cleaned pitted Siwi date fruits were blended with water at water/date ratio of $3: 1$ (wt: wt) in a blender at room temperature $\left(25^{\circ} \mathrm{C}\right)$ for $4 \mathrm{~min}$. the content was left for some time to settle and filtered through cheese cloth followed by clarification. The extract was passed through Buckner funnel under vacuum.

\section{(b) Water bath method}

$100 \mathrm{~g}$ of cleaned pitted Siwi date fruits were blended with water at water/date ratio of 3:1 (wt: wt).Blended Siwi date was placed in a glass beakers and which placed in water bath at 75 and $96^{\circ} \mathrm{C}$ for $90 \mathrm{~min}$., followed by bleaching process for $96^{\circ} \mathrm{C}$ only and filtered through Buckner funnel under vacuum.

\section{(c) Clarification}

The date extract produced at $25^{\circ} \mathrm{Cby}$ blender was clarified according to (Poel et al., 1998) method as follows:

Known weights of date extracts were used, then, saturated lime (212 g CaO / lit of water) was prepared. Original $\mathrm{PH}$ of date extract was 5.5 which increased to 9.5after lime treatment in cold condition, since this method is suitable for extracts with high rate of invert sugars. The saturated lime was added to the date juice at ambient temperature, its rate was estimated about $3 \%$ to reach $\mathrm{PH}=9.5$. The mixture of lime and extract was blended for $15 \mathrm{~min}$. by hot plate, and the temperature of the mixture was set to $60^{\circ} \mathrm{C}$, to reduce the juice viscosity. After $15 \mathrm{~min}$. coagulation of colloid compositions and transformation of weak organic acids to calcium minerals were done, $\mathrm{PH}$ of the mixture was gradually reduced to 5 by ortho-phosphoric acid $85 \%$, and filtration was done by a cotton fabric filter.

\section{(d) Centrifugation}

The color was measured according to the method of Meydav et al., (1977) as follows:

The sample date extract produced at room temperature $\left(25^{\circ} \mathrm{C}\right)$ by blender was centrifuged at $3300 \mathrm{rpm}$ for $20 \mathrm{~min}$. and the supernatant was diluted with an equal volume of alcohol (95\%) and filtered through Whatman paper No. 42. The color was measured against alcohol (95\%).

Browning was calculated as follows: Browning = Absorbance of diluted sample at $420 \mathrm{~nm}$.

Bleaching:

A known weight of the dark color date extract (Date sample was extracted in water bath at $96^{\circ} \mathrm{C}$ or date sample was extracted using $100 \%$ microwave power level) was subjected to bleaching, to improve the quality of the extracted juice, two different bleaching processes according to the method of Al-Farsi (2003) were used:

Powder-activated charcoal and filtration. The extracted 
juice was treated with $0.5 \%$ activated charcoal and the mixture heated to $60^{\circ} \mathrm{C}$ for $20 \mathrm{~min}$. followed by filtration.

Granular activated charcoal and filtration. The extracted juice was treated with $0.5 \%$ activated charcoal and the mixture heated to $60^{\circ} \mathrm{C}$ for $20 \mathrm{~min}$. followed by filtration.
The bleached date extracts were weighed and kept frozen for analysis and further processing. Efficiency of the bleaching method was followed up by browning index of the extracts before and after bleaching.

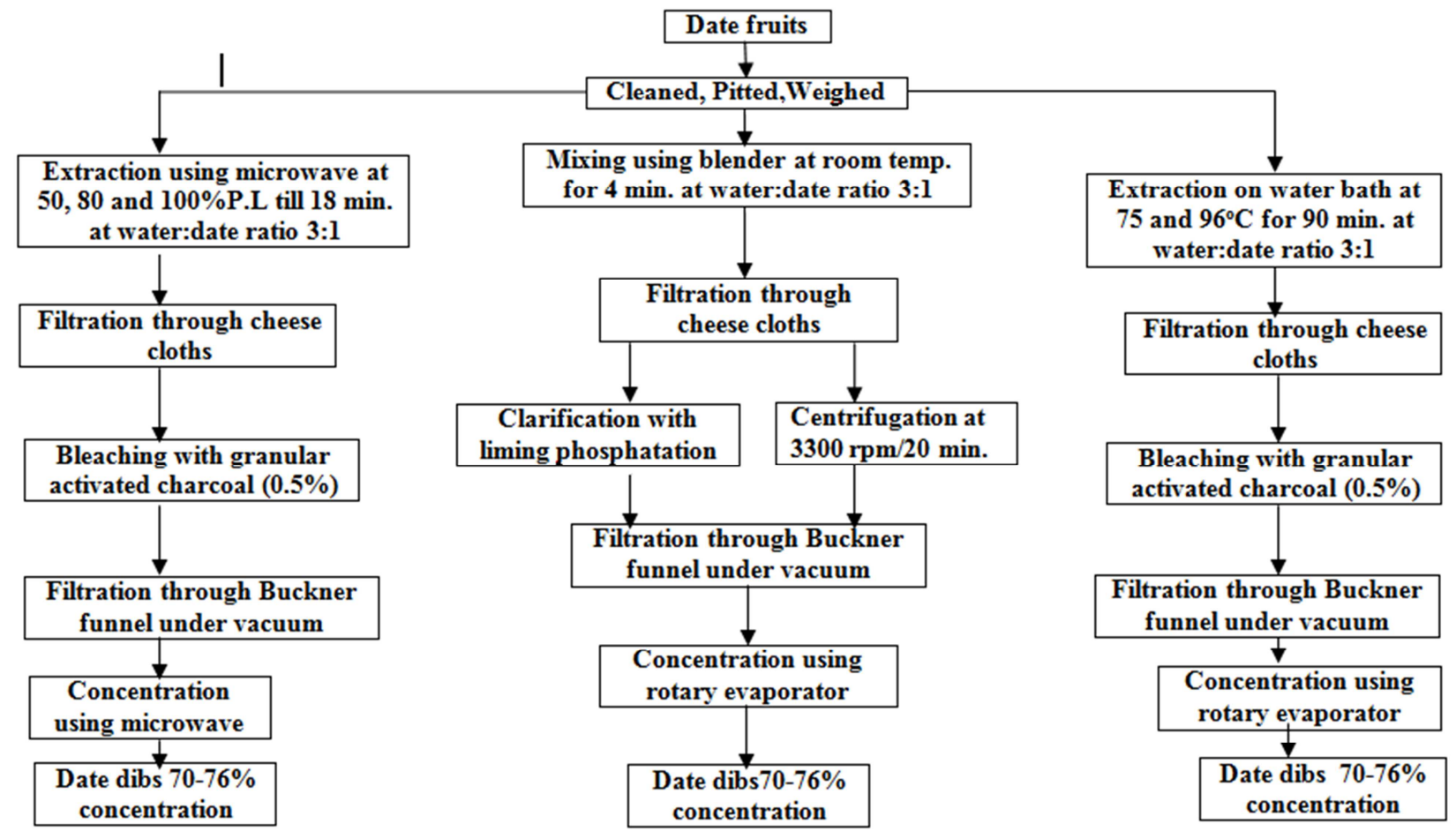

Figure 1. Flow sheet diagram of preparing date dibs on laboratory scale.

\subsection{Production of Date Syrup (Dibs)}

Samples were blended with water at water/date ratio of $3: 1$ then, known weights of the obtained extracts were concentrated as follows:

1. The obtained extract by blending at room temperature was clarified using liming phosphatation. Then, samples were concentrated under vacuum using rotary evaporator $\left(\right.$ at $\left.60^{\circ} \mathrm{C}\right)$.

2. The obtained extract by heating in water bath at $75^{\circ} \mathrm{C}$ for $90 \mathrm{~min}$. was concentrated under vacuum by rotary evaporator at $60^{\circ} \mathrm{C}$.

3. The obtained extract by heating in water bath at $96^{\circ} \mathrm{C}$ for 90 min., was divided into two divisions, the first sample was bleached by using granular activated charcoal and the second sample without bleaching as control, and then both of them was concentrated under vacuum using rotary evaporator at $60^{\circ} \mathrm{C}$.

4. The obtained extracts by using 50,80 and $100 \%$ power levels of microwave oven (1500 watt.) were concentrated using the same power levels.

The produced date syrup (dibs) was packed in sealed glass bottles and kept refrigerated for chemical analysis, microbiological evaluation and sensory evaluation.

\subsection{Physical Characteristics}

Weight percentages of flesh and pits:
Weight percentages of flesh (edible portion), and pits of Siwi date fruits were determined as a percentage of the whole fruit.

Proximate analysis:

Moisture, total soluble solids, total acidity, Crude protein, $\mathrm{PH}$, lipid and ash contens were determined according to the A.O.A.C.(2007) while total sugars and reducing sugars were determined according to Lane and Eynon method, tannins and browning were determined according to Ranganna (1979), browning index was measured according to the method of Meydav et al. (1977). Soluble pectin was determined according to the method described by Lees (1975).

\section{Microbiological analysis:}

Total bacterial count and yeast and moulds were determined according to Anon (1991), while coliform group count were determined according to Oxoid (1990).

Sensory evaluation of dibs:

Date dibs was organoleptically evaluated for its taste, color, texture and flavor according to the method of Faridi and Rubenthaler (1984) by ten panelists using a numerical basis of one to ten (where, one $=$ very bad and $10=$ excellent).

Statistical analysis:

All determinations were carried out triplicate and data is reported as mean. Significant differences $(p<0.05)$ were calculated using Duncan's. multiple range test, followed the 
method reported by Steel and Torrie(1980).

\section{Results and Discussion}

\subsection{Physical and Chemical Characteristics of Fresh Date Fruits}

Physical characteristics of Siwi date fruits.

Table 1. Physical characteristics of fresh Siwi date fruits.

\begin{tabular}{ll}
\hline Physicalcharacteristics & Siwi date \\
\hline FruitsNo./kg & 100 \\
Fruit weight $(\mathrm{g})$ & 10 \\
Flesh weight $(\mathrm{g})$ & 8.65 \\
Pitweight $(\mathrm{g})$ & 1.35 \\
Flesh/Pit ratio & 6.40 \\
Fruit flesh\% & 86.50 \\
Fruitlength $(\mathrm{cm})$ & 3.46 \\
Fruitdiameter $(\mathrm{cm})$ & 2.22 \\
Pulp thickness $(\mathrm{cm})$ & 0.81 \\
\hline
\end{tabular}

Physical characteristics of Siwi date were determined and the obtained results were presented in table (1). Data in Table (1) showed that, number of Siwi date fruits $/ \mathrm{kg}$ was 100 . On the other hand, fruit weight, flesh weight, pit weight, flesh/pit ratio, fruit flesh\%, fruit length, fruit diameter and pulp thickness were $10 \mathrm{~g}, 8.65 \mathrm{~g}, 1.35 \mathrm{~g}, 6.40,86.5 \%, 3.46 \mathrm{~cm}$, $2.22 \mathrm{~cm}$ and $0.81 \mathrm{~cm}$, respectively. These results were in agreement with those reported by Selim et al. (2012) who found that, fruit weight, weight of flesh, weight of pit, flesh $\%$, flesh/pit ratio and fruit length of Siwi date fruit were $11.25 \pm 3.2 \mathrm{~g}, 9.76 \pm 0.76 \mathrm{~g}, 1.48 \pm 0.24 \mathrm{~g}, 86.87 \pm 1.86 \%$, 6.59and $3.67 \pm 0.24 \mathrm{~cm}$,respectively.

\subsection{Chemical Characteristics of Siwi Date Fruits}

Chemical characteristics of Siwi date fruits were determined and the obtained results were tabulated in Table (2). Results showed that, moisture content, total soluble solids, total sugars, reducing sugars, non-reducing sugars, fiber, crude protein, ash, pectin, total acidity, tannins and lipid of Siwi date at tamr stage were 18.6\%, 81.4\%, 91.41\%, $86.78 \%, 4.63 \%, 2.37 \%, 2.76 \%, 0.83 \%, 1.55 \%, 0.16 \%, 0.27$ $\mathrm{mg} / 100 \mathrm{~g}$ and $1.08 \%$, respectively. These results were in a agreement with those reported by Selim et al., (2012) who found that moisture content, protein, fat, fiber and ash of Siwi date were 18.74, 1.72, 1.21, 2.62 and 2.05\%.

Table 2. Chemical characteristics of Siwi date fruits.

\begin{tabular}{ll}
\hline Chemical characteristics & Siwi date \\
\hline Moisture\% & 18.60 \\
T.S.S\% & 81.40 \\
Total sugars\%* & 91.41 \\
Reducing sugars\%* & 86.78 \\
Non-reducing sugars\%* & 4.63 \\
Crude fiber\%* & 2.37 \\
Crude protein\%* & 2.76 \\
Ash\%* & 0.83 \\
Soluble pectin\%* & 1.55 \\
Total acidity\%*(as malic acid) & 0.16 \\
Tannins(mg/100g)* & 0.27 \\
Total lipid\%* $\%$ & 1.08 \\
\hline
\end{tabular}

*On dry weight basis.

\subsection{Effect of Bleaching and Clarification Treatments on Siwi Date Extract}

Table 3. The effect of bleaching and clarification treatments on Siwi date extract quality parameters.

\begin{tabular}{|c|c|c|c|c|c|c|}
\hline $\begin{array}{ll}\text { Treatments } & \text { Parameters } \\
\end{array}$ & $\operatorname{Ash}(\%)$ & Browning absorbance(At $420 \mathrm{~nm}$ ) & Total Sugars\% & T.S.S (\%) & $\mathbf{P H}$ & Purity (\%) \\
\hline Raw juice(control) & 0.4221 & 0.138 & 18.00 & 20.40 & 6.20 & 88.20 \\
\hline PACandfiltration & 0.4167 & 0.116 & 17.10 & 19.00 & 6.10 & 90.00 \\
\hline Calcium phosphate & 0.4192 & 0.129 & 16.20 & 17.40 & 5.40 & 93.10 \\
\hline Centrifugation*andfiltration & 0.3470 & 0.108 & 17.00 & 18.90 & 6.00 & 89.94 \\
\hline
\end{tabular}

$\mathrm{PAC}=$ Powder-activated charcoal $0.5 \% . \& \mathrm{GAC}=$ granular- activated charcoal $0.5 \%$.

*Centrifugation with $3300 \mathrm{rpm}$ for $20 \mathrm{~min} \&$ Purity = total sugars/ T.S.S. x 100

The effect of bleaching using powder activated charcoal and granular activated charcoal as well as clarification by liming phosphatation and centrifugation with filtration on some quality parameters of Siwi date extract (ash, browning, total sugars, T.S.S, PH and Purity) was investigated and the obtained results were tabulated in Table (3). Presented data in table (3) showed that, granular activated charcoal had higher effect on decreasing both ash content, browning and T.S.S comparing with powder activated charcoal. Also, the treated extract by granular activated charcoal recorded higher purity $(91.39 \%)$ comparing with that treated by powder activated charcoal.
Regarding to clarification results in the same table, it could be noticed that, liming phosphatation treatment led to decrease both of total sugars, T.S.S and PH in comparison with centrifugation followed by filtration which recorded lower values in ash and browning. While (purity\%) in liming treated extract was higher than that treated by centrifugation and filtration. From the previous data, it could be concluded that, granular activated charcoal is more effective bleaching treatment than powder activated charcoal. Also, liming phosphatation is more effective clarification treatment than centrifugation and filtration as recorded by purity percentage. 


\subsection{Chemical Characteristics of the Prepared Siwi Date Dibs and Commercial Dibs}

Table 4. Chemical characteristics of the prepared siwi date dibs and Commercial dibs.

\begin{tabular}{|c|c|c|c|c|c|c|c|c|c|c|c|}
\hline Characteristics & DST1 & DST 2 & DST 3 & DST 4 & DST 5 & DST 6 & DST 7 & DST 8 & DST 9 & CDS & L.S.D \\
\hline Moisture $\%$ & $27.10^{\mathrm{A}}$ & $27.40^{\mathrm{A}}$ & $24.40^{\mathrm{G}}$ & $24.30^{\mathrm{G}}$ & $26.80^{\mathrm{B}}$ & $24.8^{\mathrm{F}}$ & $25.10^{\mathrm{E}}$ & $25.60^{\mathrm{D}}$ & $24.90^{\mathrm{E}}$ & $26.00^{\mathrm{C}}$ & 0.242 \\
\hline T.S.S\% & $96.52^{\mathrm{F}}$ & $96.83^{\mathrm{E}}$ & $98.14^{\mathrm{A}}$ & $98.28^{\mathrm{A}}$ & $97.44^{\mathrm{B}}$ & $97.47^{\mathrm{B}}$ & $96.26^{\mathrm{G}}$ & $97.17^{\mathrm{CD}}$ & $97.33^{\mathrm{BC}}$ & $95.54^{\mathrm{H}}$ & 0.225 \\
\hline Total sugars $\%$ & $89.15^{\mathrm{G}}$ & $90.72^{\mathrm{D}}$ & $93.82^{\mathrm{A}}$ & $93.94^{\mathrm{A}}$ & $92.33^{\mathrm{B}}$ & $85.77^{\mathrm{H}}$ & $89.62^{\mathrm{F}}$ & $90.45^{\mathrm{E}}$ & $90.97^{\mathrm{C}}$ & $79.71^{\mathrm{I}}$ & 0.138 \\
\hline Red. Sugars\% & $81.34^{\mathrm{F}}$ & $88.76^{\mathrm{C}}$ & $91.69^{\mathrm{A}}$ & $91.95^{\mathrm{A}}$ & $90.42^{\mathrm{B}}$ & $83.98^{\mathrm{E}}$ & $87.65^{\mathrm{D}}$ & $88.60^{\mathrm{C}}$ & $89.02^{\mathrm{C}}$ & $71.80^{\mathrm{G}}$ & 0.782 \\
\hline Non-red. Sugars $\%$ & $2.31^{\mathrm{B}}$ & $1.96^{\mathrm{CDE}}$ & $2.13^{\mathrm{C}}$ & $1.99^{\mathrm{CD}}$ & $1.91^{\mathrm{DE}}$ & $1.79^{\mathrm{E}}$ & $1.97^{\mathrm{CDE}}$ & $1.85^{\mathrm{DE}}$ & $1.94^{\mathrm{DE}}$ & $7.96^{\mathrm{A}}$ & 0.167 \\
\hline Ash $\%$ & $2.24^{\mathrm{B}}$ & $1.39^{\mathrm{G}}$ & $2.10^{\mathrm{D}}$ & $1.96^{\mathrm{E}}$ & $1.64^{\mathrm{F}}$ & $2.13^{\mathrm{CD}}$ & $2.21^{\mathrm{BC}}$ & $1.98^{\mathrm{E}}$ & $2.00^{\mathrm{E}}$ & $3.56^{\mathrm{A}}$ & 0.083 \\
\hline Tannins $\%$ & $0.44^{\mathrm{A}}$ & $0.39^{\mathrm{AB}}$ & $0.32^{\mathrm{BCD}}$ & $0.29^{\mathrm{CD}}$ & $0.23^{\mathrm{E}}$ & $0.39^{\mathrm{AB}}$ & $0.28^{\mathrm{DE}}$ & $0.33^{\mathrm{BCD}}$ & $0.29^{\mathrm{CD}}$ & $0.13^{\mathrm{F}}$ & 0.054 \\
\hline Acidity(as malic acid) & $0.53^{\mathrm{C}}$ & $0.17^{\mathrm{F}}$ & $0.17^{\mathrm{F}}$ & $0.11^{\mathrm{G}}$ & $0.53^{\mathrm{C}}$ & $0.56^{\mathrm{B}}$ & $0.11^{\mathrm{G}}$ & $0.51^{\mathrm{D}}$ & $0.31^{\mathrm{E}}$ & $0.73^{\mathrm{A}}$ & 0.015 \\
\hline $\mathrm{PH}$ & $5.30^{\mathrm{CD}}$ & $6.60^{\mathrm{B}}$ & $6.60^{\mathrm{B}}$ & $6.80^{\mathrm{A}}$ & $5.30^{\mathrm{CD}}$ & $5.20^{\mathrm{DE}}$ & $6.80^{\mathrm{A}}$ & $5.40^{\mathrm{C}}$ & $6.10^{\mathrm{AB}}$ & $5.10^{\mathrm{E}}$ & 0.154 \\
\hline Browning(at420nm) & $.142^{\mathrm{I}}$ & $.116^{\mathrm{J}}$ & $.223^{\mathrm{G}}$ & $.281^{\mathrm{E}}$ & $.198^{\mathrm{H}}$ & $.256^{\mathrm{F}}$ & $.329^{\mathrm{D}}$ & $.624^{\mathrm{C}}$ & $.871^{\mathrm{B}}$ & $.985^{\mathrm{A}}$ & 9.788 \\
\hline Browningindex & $.106^{\mathrm{I}}$ & $.104^{\mathrm{J}}$ & $.185^{\mathrm{G}}$ & $.206^{\mathrm{E}}$ & $.178^{\mathrm{H}}$ & $.202^{\mathrm{F}}$ & $.286^{\mathrm{D}}$ & $.353^{\mathrm{C}}$ & $.401^{\mathrm{B}}$ & $.494^{\mathrm{A}}$ & 0.001 \\
\hline Date syrup yield $\%$ & $65.17^{\mathrm{H}}$ & $63.61^{\mathrm{I}}$ & $79.53^{\mathrm{B}}$ & $79.91^{\mathrm{A}}$ & $78.34^{\mathrm{C}}$ & $77.69^{\mathrm{D}}$ & $76.44^{\mathrm{E}}$ & $75.12^{\mathrm{F}}$ & $71.61^{\mathrm{G}}$ & ----- & 0.354 \\
\hline
\end{tabular}

*Date syrup yield(Dibs): Quantity of date syrup produced/quantity of the pitted date used.

*DST (1): Date dibs of the extract by blender at room temp and concentration under vacuum.

*DST (2): Date dibs of the extractby blender at room tempand concentration under vacuum after clarification using liming phosphatation.

*DST (3): Date dibs of the extract of water bath at $75^{\circ} \mathrm{C} / 90$ min. and concentration under vacuum.

*DST (4): Date dibs of the extract of water bath at $96^{\circ} \mathrm{C} / 90$ min. and concentration under vacuum.

*DST (5): Date dibs of the extract ofwater bath at $96^{\circ} \mathrm{C} / 90 \mathrm{~min}$. and concentration undervacuum after bleaching using granular activated charcoal at $0.5 \%$ level.

*DST (6): Date dibs producedmicrowave extract and concentration at $50 \%$ power level.

*DST (7): Date dibs producedmicrowave extract and concentration at $80 \%$ power level.

*DST (8): Date dibs producedmicrowave extract and concentration at 100\% power level.

*DST (9): Date dibs of the extract of water bath at $75^{\circ} \mathrm{C} / 90 \mathrm{~min}$. and concentration on hot plate.

*CDS: Commercial date dibs from local market

The chemical characteristics of produced dibs from Siwi date using different methods were determined and the obtained results were tabulated in Table (4). From the presented data it could be noticed that, using $96^{\circ} \mathrm{C}$ extraction and concentration under vacuum and $75^{\circ} \mathrm{C}$ extraction and concentration under vacuum recorded the lowest moisture content (24.3 and $24.4 \%$, respectively) comparing with other studied treatments. Concerning to T.S.S (on dry weight basis) it could be noticed that, the highest T.S.S was recorded for the dibs obtained using $96^{\circ} \mathrm{C}$ extraction and concentration under vacuum and $75^{\circ} \mathrm{C}$ extraction and concentration under vacuum (98.28 and 98.14,respectively) followed by dibs obtained using $50 \%$ microwave power level (97.47). On the other hand, using extraction at 96 and $75^{\circ} \mathrm{C}$ under vacuum concentration had the highest total and reducing sugars (93.94 and $91.95 \%$, and 93.82 and $91.69 \%$, respectively.) followed by $96^{\circ} \mathrm{C}$ extraction under vacuum with bleaching process (92.33 and $90.42 \%$, respectively). While the highest ash content was recorded for commercial sample followed by blender extraction and concentration under vacuum(3.56 and $2.24 \%$,respectively) Concerning to pectin content results in Table (4), it could be indicated that, commercial sample had the highest pectin content $(0.72 \%)$ followed by $80 \%$ microwave power level and blender extraction and concentrated under vacuum ( 0.66 and $0.61 \%$, respectively). While the lowest pectin content was recorded for the sample extracted by blender and concentrated under vacuum with clarification process $(0.24 \%)$. Meanwhile, the highest tannins content was recorded for blender extraction and concentration under vacuum $(0.44 \mathrm{mg}$ as tannic acid/100gm of dry weight) followed by both of extraction by blender and concentrated under vacuum with clarification process and $50 \%$ microwave power level $(0.39 \mathrm{mg}$ as tannic acid $/ 100 \mathrm{gm})$. Regarding to acidity and PH results in Table (4), it could be observed that commercial sample had the highest acidity and the lowest PH followed by $50 \%$ microwave power level.

\subsection{Sensory Evaluation of Dibs}

Organoleptic characteristics of Siwi dibs extracted by different methods with and without bleaching and clarification treatments were evaluated and the obtained results were tabulated in Table (5). The data that the highest color scores were recorded for Siwi dibs extracted by blender at room temperature (with and without clarification treatment) and concentrated under vacuum at $60^{\circ} \mathrm{C}(9.16)$. While the highest texture, taste and flavor scores were recorded for Siwi dibs extracted at $75^{\circ} \mathrm{C}$ for $90 \mathrm{~min}$. and concentrated on hot plate (8.83, 9.33 and 9.33) in comparison with the other studied treatments. In relation to browning and browning index results, data in Table (5) illustrated that, the highest values were recorded for commercial sample $(0.985$ and 0.494 , respectively), followed by sample concentrated by hot plate which recorded 0.871 and 0.401 , respectively, while the lowest values were recorded for the sample extracted by blender and concentrated under vacuum with clarification process ( 0.116 and 0.104 , respectively).Results of date syrup yield indicated that, the highest yield was obtained using water bath at $96^{\circ} \mathrm{C}$ extraction and concentration under vacuum followed by water bath at $75^{\circ} \mathrm{C}$ extraction and 
concentration under vacuum where their yields were 79.91 and $79.53 \%$, respectively.

Results of all date dibs treatments were within acceptable limits as recommended by Egyptian standard (2006) which states that the proportions of moisture $(\leq 25 \%)$, TSS $(\geq 75 \%)$, total sugars $(\geq 69 \%)$, ash $(\leq 1.8 \%)$, pectin $(\leq 0.25 \%)$, acidity $(\leq 0.46 \%), \mathrm{PH}(\geq 4.6)$ and tannins $(\leq 0.1 \%)$.

Table 5. Sensory evaluation of Siwi date dibs.

\begin{tabular}{lllll}
\hline \multicolumn{1}{c}{ Parameters } & Color & Texture & Taste & Flavor \\
\hline Datender extraction & $9.16^{\mathrm{a}}$ & $7.16^{\mathrm{ab}}$ & $7.50^{\mathrm{bc}}$ & $8.50^{\mathrm{a}}$ \\
Clarification & $9.16^{\mathrm{a}}$ & $6.16^{\mathrm{b}}$ & $7.00^{\mathrm{c}}$ & $8.33^{\mathrm{a}}$ \\
Water b. $75^{\circ} \mathrm{Cu} . \mathrm{v}$ & $8.66^{\mathrm{a}}$ & $8.58^{\mathrm{a}}$ & $8.08^{\mathrm{abc}}$ & $8.66^{\mathrm{a}}$ \\
Water.b96 $6^{\circ} \mathrm{Cu} . \mathrm{v}$ & $8.16^{\mathrm{ab}}$ & $8.41^{\mathrm{a}}$ & $8.25^{\mathrm{abc}}$ & $8.66^{\mathrm{a}}$ \\
W.b $96^{\circ} \mathrm{C}-\mathrm{A} \mathrm{C.u.v}$ & $8.66^{\mathrm{a}}$ & $8.25^{\mathrm{a}}$ & $8.75^{\mathrm{ab}}$ & $9.08^{\mathrm{a}}$ \\
Microwave $50 \%$ & $8.25^{\mathrm{a}}$ & $7.83^{\mathrm{ab}}$ & $7.83^{\mathrm{bc}}$ & $8.16^{\mathrm{a}}$ \\
Microwave $80 \%$ & $8.41^{\mathrm{a}}$ & $7.16^{\mathrm{ab}}$ & $7.50^{\mathrm{bc}}$ & $9.00^{\mathrm{a}}$ \\
Microwave $100 \%$ & $7.83^{\mathrm{ab}}$ & $8.16^{\mathrm{a}}$ & $8.16^{\mathrm{abc}}$ & $8.66^{\mathrm{a}}$ \\
Hotplate & $6.66^{\mathrm{bc}}$ & $8.83^{\mathrm{a}}$ & $9.33^{\mathrm{a}}$ & $9.33^{\mathrm{a}}$ \\
Commercial dibs & $6.00^{\mathrm{c}}$ & $8.50^{\mathrm{a}}$ & $7.00^{\mathrm{c}}$ & $8.80^{\mathrm{a}}$ \\
L.S.D & 1.4142 & 1.5420 & 1.2590 & 1.042 \\
\hline
\end{tabular}

\subsection{Microbiological Quality}

The effect of processing on microbiological quality of Siwi date dibs extracted by different methods was examined and the obtained results were tabulated in Table (6). The presented data showed that, Siwi date dibs extracted by blender at room temperature for $5 \mathrm{~min}$. and then concentrated under vacuum at $60^{\circ} \mathrm{C}$ had the highest total bacterial count and yeast and mould count.

Table 6. Effect of processing on total Bacterial count, yeast and moulds and Coliform group count (cell/g) of Siwi dibs.

\begin{tabular}{llll}
\hline Samples & $\mathbf{B 1 0}^{\mathbf{4}}$ & Y+ M10 $^{1}$ & $\mathbf{C 1 0}^{\mathbf{1}}$ \\
\hline Blender extraction & 2.26 & 6.00 & 2.33 \\
Clarification & 1.93 & 4.00 & 2.66 \\
Water b. $75^{\circ} \mathrm{Cu} . \mathrm{v}$ & 2.15 & 3.33 & 2.00 \\
Water.b96 ${ }^{\circ} \mathrm{Cu} . \mathrm{v}$ & 1.73 & 1.33 & 1.00 \\
W.b $96^{\circ} \mathrm{C}-\mathrm{G} . \mathrm{A} . \mathrm{C}-\mathrm{u} . \mathrm{v}$ & 2.11 & 2.00 & 1.66 \\
Microwave $50 \%$ & 2.10 & 2.00 & 1.66 \\
Microwave $80 \%$ & 2.00 & 1.66 & 1.33 \\
Microwave $100 \%$ & 1.33 & 1.30 & 0.66 \\
Hotplate & 1.93 & 1.33 & 1.00 \\
Commercial dibs & 1.81 & 1.88 & 1.00 \\
\hline
\end{tabular}

B:Total Bacterial count $Y+M$ :Yeast and Moulds countC: Coliform group countu.v: under vacuumG.A.C: granular activated charcoal.

While Siwi date dibs that extracted by blender at room temperature for $5 \mathrm{~min}$. and clarified by liming phosphatation then concentrated at $60^{\circ} \mathrm{C}$ under vacuum had the highest coliform group count. On the other hand, Siwi date dibs extracted at $100 \%$ microwave power level, recorded the lowest values for total bacterial count, yeast and mould count and coliform group count followed by date dibs extracted at $96^{\circ} \mathrm{C}$ for $90 \mathrm{~min}$. then concentrated under vacuum at $60^{\circ} \mathrm{C}$, while Siwi date dibs produced from hot plate was recorded for both yeast and mould count and coliform group count.

\section{References}

[1] Agricultural Research Center, Horticultural research Institute, 2016 statistical.

[2] Al-Farsi, M. A. (2003). Clarification of date juice. International Journal of Food Science and Technology, 38, 241-245.

[3] Almaan, H. A. and R. M. Mohamed. (1991). Effect of Date Syrup on Starch Gelatinization and Quality of Layer Cakes. Cereal Foods World. American Society of Cereal Chemists.36: (12), 1010-1012.

[4] Anon. (1991). Biolife manual. Second edition. Printed by Ingraf, Milan, Italy.

[5] A. O. A. C. (2007). Official Methods of Analysis of the Association of Official Analytical Chemists.18 ed. Published by A. O. A. C. Washington, D. C. (U. S. A.).

[6] Ashraf, Z. and Z. Hamidi-Esfahani, (2011). Date and date processing. Food Reviews International. 27: 2, 101-133.

[7] Barreveld, W. H. 1993. Date palm products. FAO Agric. Services, Bulletin ISSN, pp. 1010.

[8] Batu, A. (1993). Kuruüzüm vepek mezinins ansağlığıvees lenmesiaçısın danönemi (The importanceo fraisin and pekmez on human health and nutrition), Gida. 18(5), 303-307.

[9] Egyptian standards (2006).Date dibs or Date syrup. ES: 3074/ 2006, Egyptian Organization for Standardization and Quatlity. Arab Republic of Egypt.

[10] El-Samahy, S. K, Habiba, R. A., and Gab-Allah, A. A. 2003. Preparation of protein-fortification of date bars. The International conference on Date Palm, King Saud Univ., Qaseem, Saudi Arabia, pp. 405-425.

[11] El-Samahy, S. K., and Youssef, K. M. 2009: Physico-chemical and rheologicalproperties of date fruitsextract during concentration Alex. J. Fd. Sci. \& Technol. 6: 85-93.

[12] Faridi, H. A. and Rubenthaler, G. L. (1984). Effectof baking time and temperature onbread quality, starch gelatinization, and staling of Egyptian balady bread. CerealChemistry, 61 (2): 151-154.

[13] Lees, R. (1975). Food analysis: "Analytical and quality control methods for the food manufacturer and buyer." $3^{\text {rd }}$ Ed., Published by Lenoard Hill books, London, England.

[14] MALR. 2001. Ministry of Agriculture and Land Reclamation, Economic Affairs Sector (EAS), Agriculture Planning Central Administration, General Administration of Agric. Economic Resources, National Agricultural Income, pp. 74-79.

[15] Meydav, S.; Saguy, I. and Kopelman, I. J. (1977). Browning determination in citrus products. J. Agric. Food Chem., 25(3), 802-804.

[16] Mostafa, G. A., El-Samahy, S. K., Abd El-Hady, E. A., and Abd El-Fadeel, M. G. 2002. Production ofdate nectars. Annals Agric. Sci., Ain Shams Univ., Cairo 47: 695-705.

[17] Oxoid. (1990). The oxoid manual of culture. Media and Other Laboratory Services. Fourth edition. 
[18] Poel, P. W; Schiweck, H; Schwartz, T. K; Foundation, B.S.D.(1998). Sugar technology: beet and cane sugar manufacture. Berlin. 25-40 P.

[19] Ranganna, S.(1979). "Manual of analysis of fruit and vegetable products." Tata Mc Graw-Hill Publishing Co. Limited, New Delhi.

[20] Selim, K.; M. AbdEl-Bary and O. Ismaael, (2012). Effect of irradiation and heat treatments on the quality characteristics of
Siwi date fruit (Phoenx dactylifera L.). AgroLife Scientific Journal - Volume 1, CD-ROM ISSN 2285-5726; ISSN-L 2285-5718.

[21] Steel, R.G. and J.H. Torrie. (1980). Principles and Procedures of Statistics, a Biometrical Approach. Mc Grow- Hill.

[22] Yousif, A-K., Al-Shaawan, A. F., Mininah, M. Z., and ElTaisan, S. M. 1987. Processing of date preserve, date jelly and date jutter. Date Palm J. 5: 73-86. 